\title{
ISOLASI DAN KARAKTERISASI PROTEASE ALKALIN DARI ISOLAT BAKTERI LIMBAH TERNAK DI EXFARM FAKULTAS PETERNAKAN UNSOED
}

\author{
Zusfahair, Puji Lestari, Ari Asnani \\ Program Studi Kimia, Jurusan MIPA, Fakultas Sains dan Teknik, UNSOED
}

\begin{abstract}
Protease is one of the widely used enzymes for the industry. The potential resource of microorganism that produced protease is milk cow waste. In this research, isolation and characterization has been done toward isolated protease from milk cow waste of the Exfarm's Animal Husbandry Faculty at University of Jenderal Soedirman, Purwokerto. The research used experiment method and the parameters observed were the genus of bacteria which produce protease and the activity of protease. The characterizations of protease were determination of optimum $\mathrm{pH}$ and temperature, the influence of metal ions, EDTA, surfactant, and commercial detergent toward enzyme activity, and also the study of enzyme stability. The results from the research showed that the isolated bacteria from the Exfarm's of Animal Husbandry Faculty of UNSOED, which produced protease was Salmonella sp. Characterization of isolated Salmonella sp. from $45 \%$ ammonium sulphate fraction indicated that the optimum temperature was $50{ }^{\circ} \mathrm{C}$, optimum $\mathrm{pH}$ was 8 , the enzyme was activated by $\mathrm{Ca}^{2+}$ dan $\mathrm{Mg}^{2+}$ ion, whereas it was inhibited by $\mathrm{Zn}^{2+}, \mathrm{Cu}^{2+}$ ions and EDTA. The addition of Tween- 80 with the concentration of $0.2 \%$ and $0.4 \%$ increased protease activity, however the addition of Tween- 80 with concentration higher than $0.6 \%$ decreased the protease activity. Enzyme protease from isolated Salmonella sp. was relatively stable with the addition of commercial detergent such as Attack, Surf, and Bukrim.
\end{abstract}

Keyword : Protease, milk cow waste, detergent industry.

\section{PENDAHULUAN}

Fakultas Peternakan UNSOED mengelola peternakan sapi yang menghasilkan limbah dan ditampung dalam tanki penampungan limbah. Selama ini limbah tersebut belum dimanfaatkan secara optimum. Salah satu alternatif pemanfaatan limbah tersebut adalah sebagai sumber mikroorganisme penghasil protease. Hal ini karena limbah tersebut mengandung nutrien yang berpotensi sebagai medium pertumbuhan mikroorganisme penghasil protease.

Protease merupakan salah satu enzim yang banyak digunakan dalam bidang industri. Secara komersial protease menduduki urutan tertinggi di antara enzim lainnya dan mencakup lebih dari $60 \%$ total penjualan enzim (Adinaraya, dkk., 2003). Kebutuhan protease di Indonesia hampir 100\% berasal dari impor. Akhir-akhir ini penggunaan protease alkalin semakin meningkat di dalam berbagai proses industri seperti di dalam industri detergen. Industri detergen memerlukan enzim dengan $\mathrm{pH}$ tinggi, rentang suhu luas dan stabil terhadap senyawasenyawa yang terkandung dalam detergen seperti surfaktan, agen pemutih, aktivator pemutih, pelembut serat dan bahan lainnya (Noguiera, 2006).

Penelitian ini bertujuan melakukan isolasi dan karakterisasi protease bakteri dari limbah sapi perah. Karakterisasi protease meliputi penentuan $\mathrm{pH}$ dan suhu optimum, penentuan pengaruh ion logam, EDTA, surfaktan, dan detergen komersial 
terhadap aktivitas enzim serta uji stabilitas enzim.

\section{METODE PENELITIAN}

Materi utama dari penelitian ini adalah limbah sapi perah dari Exfarm Fakultas Peternakan Unsoed Purwokerto. Bahan yang digunakan adalah bakteri isolat hasil isolasi dari limbah sapi perah; medium NA (Nutient Agar); medium NB (Nutrient Broth); skim milk, reagen TCA (asam trikloro asetat $0,11 \mathrm{M}$, natrium asetat $0,22 \mathrm{M}$, asam asetat $0,33 \mathrm{M}$ ); tirosin $(0-100 \mu \mathrm{g} / \mathrm{mL})$; substrat kasein $(0,6 \mathrm{~b} / \mathrm{v})$ dalam buffer Tris-HCl $0,1 \mathrm{M}$ pH 8,0; buffer pospat; buffer sitrat; buffer asetat; EDTA $10^{-3} \mathrm{M}$; akuades; $\mathrm{CaCl}_{2}$; $\mathrm{ZnCl}_{2} ; \mathrm{MgCl}_{2} ; \mathrm{FeSO}_{4} ; \mathrm{MnSO}_{4} ; \mathrm{SDS}$; Tween-80. Alat yang digunakan antara lain tabung reaksi, gelas ukur, cawan petri, pipet ukur, pipet mikro, gelas piala, labu erlenmeyer, autoklaf, shaker incubator, hot plate, sentrifugator, neraca analitik, $\mathrm{pH}$ meter, jarum ose, pipet mikro, labu pengenceran, dan spektrofotometer UV-Visible (shimadzu).

\section{Pengambilan Sampel}

Sampel limbah diambil 3 titik secara acak pada tangki penampungan limbah. Limbah dimasukkan ke dalam botol yang sudah disterilkan. Pengambilan sampel diawali dengan pengukuran suhu dan $\mathrm{pH}$ limbah tersebut secara in situ.

\section{Isolasi Bakteri Penghasil Protease}

Sampel tanah dibuat suspensi dengan menambahkan 2 gram sampel tanah pada $10 \mathrm{~mL}$ aquades steril, kemudian sebanyak 0,1 mL suspensi ditambahkan pada medium NA dengan cara sebaran. Inkubasi dilakukan selama $2 \times 24$ jam pada suhu sesuai habitat asalnya, selanjutnya dilakukan pengamatan terhadap koloni yang tumbuh pada medium NA. Koloni yang menunjukkan kenampakan yang berbeda ditumbuhkan pada medium NA secara goresan dan diinkubasi pada suhu sesuai habitat asalnya selama $2 \times 24$ jam untuk mendapatkan isolat murni (koloni tunggal).

\section{Penapisan Kualitatif}

Kemampuan bakteri dalam menghidrolisis protein ditandai dengan pembentukan zona jernih, caranya satu ose koloni digoreskan pada medium SMA pH 9. Piaraan diinkubasi pada suhu yang sesuai dengan habitat asal selama $2 \times 24$ jam dan diamati terbentuknya zona jernih pada masingmasing koloni. Koloni yang membentuk zona jernih merupakan penghasil protease dan digunakan untuk penelitian selanjutnya meliputi identifikasi isolat bakteri, penentuan kurva produksi, ektraksi, fraksinasi, dan karakterisasi enzim protease.

\section{Identifikasi Bakteri}

Identifikasi dilakukan di Laboratorium Mikrobiologi Fakultas Biologi Universitas Jendral Soedirman Purwokerto

\section{Pembuatan Inokulum}

Inokulum dibuat dengan memindahkan isolat bekteri penghasil protease dari medium agar steril ke dalam $25 \mathrm{~mL}$ medium NB menggunakan jarum ose secara aseptis dan dikocok (dengan shaker) selama 1x24 jam pada suhu sesuai habitat asal.

\section{Penentuan Waktu Produksi Optimum dan Fase Pertumbuhan Bakteri}

Inokulum sebanyak $10 \%$ dimasukkan ke dalam medium NB dan diinkubasi. Waktu produksi optimum enzim dan fase pertumbuhan bakteri ditentukan berturut-turut dengan melakukan uji aktivitas ekstrak kasar medium dan mengukur kekeruhan menggunakan panjang gelombang 600 nm pada jam ke-0, 6, 12, 18, 24, 30, 36, 42, dan 48. Data yang diperoleh dibuat 
grafik dan waktu produksi optimum yang didapat digunakan untuk produksi enzim protease pada penelitian selanjutnya.

\section{Produksi Protease}

Produksi protease dilakukan dengan cara memindahkan 10-15\% biakan bakteri dari medium inokulum ke dalam medium NB. Medium produksi selanjutnya diinkubasi selama waktu produksi optimum pada suhu sesuai habitat asal.

\section{Ekstraksi Protease}

Bakteri hasil biakan pada medium produksi dipanen dengan cara sentrifugasi pada kecepatan $4000 \mathrm{rpm}$ selama 10 menit, dalam keadaan dingin suhu $4{ }^{\circ} \mathrm{C}$, sehingga diperoleh endapan dan supernatan. Supernatan yang diperoleh adalah ekstrak kasar enzim protease ekstraseluler dan selanjutnya dilakukan fraksinasi.

\section{Fraksinasi Protease}

Ekstrak kasar medium diukur volumenya, ditambah x gram amonium sulfat sampai konsentrasi akhir $15 \%$ (b/v), kemudian disentrifugasi. Supernatan ditampung, sedangkan endapan yang tertinggal dilarutkan dengan $5 \mathrm{~mL} \mathrm{NaCl} 1 \% \quad(\mathrm{~b} / \mathrm{v})$ dan disimpan pada suhu $4{ }^{\circ} \mathrm{C}$ sebagai fraksi endapan $15 \%$ (FE-15\%). Supernatan ditambahkan lagi amonium sulfat sampai konsentrasi akhir 30\% dan disentrifuse lagi. Supernatan ditampung, sedangkan endapan yang tertinggal dilarutkan dengan $5 \mathrm{ml} \mathrm{NaCl} 1 \%$ (b/v) dan disimpan pada suhu $4{ }^{\circ} \mathrm{C}$ sebagai fraksi endapan $30 \%$ (FE-30\%). Hal yang sama dilakukan dengan konsentrasi akhir amonium sulfat $45 \%$ dan $60 \%$, sehingga diperoleh fraksi endapan $15 \%, 30 \%$, $45 \%, 60 \%$ dan fraksi supernatan $60 \%$ (FE-15\%, FE-30\%, FE-45\%, FE-60\% dan FS-60\%). Fraksi-fraksi tersebut kemudian didialisis.
Dialisis Hasil Fraksinasi (Bollag, et. al., 1996)

$\begin{array}{rlr}\text { Hasil } & \text { fraksinasi } & \begin{array}{r}\text { yang } \\ \text { garam, }\end{array} \\ \text { didialisis }\end{array}$ menggunakan kantong selofan dengan akuades sebagai cairan pencuci. Fraksifraksi tersebut dimasukkan ke dalam kantong selofan dan diikat bagian atas dan bawahnya. Dialisis dilakukan pada suhu $4{ }^{\circ} \mathrm{C}$ sambil diaduk dengan magnetic stirer dengan penggantian akuades setiap 30 menit hingga larutan enzim tidak mengandung garam. Fraksifraksi hasil dialisis yang diperoleh diuji aktivitas dan kadar proteinnya. Fraksi hasil dialisis yang memiliki aktivitas tertinggi ditentukan $\mathrm{pH}$ optimum, suhu optimum, pengaruh ion-ion logam $\left(\mathrm{CaCl}_{2}, \mathrm{ZnCl}_{2}, \quad \mathrm{MgCl}_{2}\right.$, dan $\mathrm{FeSO}_{4}$, $\mathrm{MnSO}_{4}$ ), EDTA, surfaktan, dan detergen komersial terhadap aktivitas enzim serta uji stabilitas enzim.

\section{Uji Aktivitas Protease (Fuad dkk, 2004)}

Aktivitas proteolitik protease diukur dengan metode Kunitz yang dimodifikasi. Sebanyak $0,5 \mathrm{~mL}$ substrat kasein $(0,6 \mathrm{~b} / \mathrm{v})$ dalam buffer Tris- $\mathrm{HCl}$ $0,1 \mathrm{M} \mathrm{pH} 8,0$ diprainkubasi pada suhu 45 ${ }^{\circ} \mathrm{C}$ selama 5 menit. Reaksi enzim dimulai dengan menambahkan $0,1 \mathrm{~mL}$ ekstrak enzim ke dalam substrat dan diinkubasi pada suhu $45{ }^{\circ} \mathrm{C}$ selama 30 menit. Reaksi dihentikan dengan menambahkan $0,5 \mathrm{~mL}$ TCA (asam trikloroasetat $0,11 \mathrm{M}$, Naasetat $0,22 \mathrm{M}$, asam asetat $0,33 \mathrm{M}$ ) dalam keadaan dingin. Campuran uji dibiarkan mengendap selama 30 menit lalu disentrifugasi $4000 \mathrm{rpm} 4{ }^{\circ} \mathrm{C}$ selama 15 menit. Peptida terlarut dalam supernatan hasil hidrolisis diukur dengan spektrofotometer pada panjang gelombang $275 \mathrm{~nm}$. Larutan kontrol dibuat dengan perlakuan sama, tetapi substrat ditambah TCA terlebih dahulu baru kemudian ditambah larutan enzim. Larutan tirosin $(0-100 \mu \mathrm{g} / \mathrm{mL})$ digunakan sebagai standar untuk pengukuran 
aktivitas proteolitik. Satu unit aktivitas protease (U) didefinisikan sebagai jumlah enzim yang diperlukan untuk menghasilkan $1 \mu \mathrm{g}$ tirosin/menit $/ \mathrm{mL}$ larutan enzim dari substrat kasein pada kondisi pengujian tersebut.

\section{Penetapan Suhu Optimum Enzim}

Prosedur kerja penetapan suhu optimum enzim sama seperti pada uji aktivitas tetapi dengan variasi suhu yaitu pada suhu $30{ }^{\circ} \mathrm{C}, 40{ }^{\circ} \mathrm{C}, 45{ }^{\circ} \mathrm{C}, 50{ }^{\circ} \mathrm{C}, 55$ ${ }^{\circ} \mathrm{C}, 60{ }^{\circ} \mathrm{C}, 65{ }^{\circ} \mathrm{C}$, dan $70{ }^{\circ} \mathrm{C}$.

\section{Penentuan pH Optimum}

Prosedur kerja penetapan $\mathrm{pH}$ optimum enzim sama seperti pada penetapan suhu optimum, tetapi dengan variasi $\mathrm{pH}$. Variasi $\mathrm{pH}$ yang dilakukan adalah $6,7,8,9$, dan 10 pada suhu optimum. Substrat yang digunakan adalah kasein $0,6 \%(b / v)$.

\section{Penentuan Pengaruh Ion Logam dan EDTA}

Pengaruh ion logam terhadap aktivitas protease ditentukan dengan cara menambahkan ion logam ke dalam larutan sampel saat uji aktivitas pada $\mathrm{pH}$ dan suhu optimum. Ion logam yang digunakan adalah $\mathrm{CaCl}_{2}, \mathrm{ZnCl}_{2}, \mathrm{MgCl}_{2}$, dan $\mathrm{FeSO}_{4}, \mathrm{MnSO}_{4}$, masing-masing dengan konsentrasi akhir $10^{-3} \mathrm{M}$, selanjutnya diuji aktivitasnya menggunakan metode Kunitz yang dimodifikasi. Penentuan pengaruh EDTA terhadap aktivitas protease ditentukan dengan cara menambahkan EDTA dengan konsentrasi akhir $10^{-2} \mathrm{M}$ ke dalam larutan sampel pada saat uji aktivitas pada $\mathrm{pH}$ dan suhu optimum.

\section{Penentuan Pengaruh Surfaktan (Noguiera, et al., 2006). \\ Pengaruh surfaktan terhadap aktivitas protease diuji dengan cara menambahkan Sodium Dodesil Sulfat (SDS) dan Tween-80 pada variasi konsentrasi 0,$2 ; 0,4 ; 0,6 ; 0,8 ; 1,0 \%$ ke}

dalam larutan sampel, selanjutnya diinkubasi pada suhu dan $\mathrm{pH}$ optimum. Pengukuran aktivitas protease dilakukan dengan metode Kunitz yang dimodifikasi.

\section{Penentuan Pengaruh Detergen Komersial terhadap stabilitas enzim (Jaswal and Kocher, 2007)}

Detergen yang digunakan adalah detergen komersial yang ada di pasaran. Detergen dilarutkan dengan air sesuai petunjuk pemakaian yang tertera pada bungkusnya. Uji dilakukan dengan menambahkan $0,9 \mathrm{~mL}$ detergen pada 0,1 $\mathrm{mL}$ enzim kemudian diinkubasi selama 8 jam dengan sampling setiap 30 menit untuk diuji aktivitas sisanya dengan metode Kunitz yang dimodifikasi. Kontrol digunakan prosedur yang sama tanpa penambahan detergen.

\section{HASIL DAN PEMBAHASAN Isolasi Bakteri Penghasil Protease}

Bakteri penghasil protease diisolasi dari limbah tanki penampungan limbah pada suhu $35{ }^{\circ} \mathrm{C}$ dan $\mathrm{pH} 8$ saat pengukuran secara insitu. Sampel limbah yang berupa tanah dibuat suspensi kemudian ditumbuhkan pada medium cawan Nutrient Agar (NA) secara spread platting. Isolat bakteri yang memiliki kenampakan berbeda pada medium cawan NA kemudian dipindahkan ke medium NA baru dengan metode cawan gores kuadran, sehingga diperoleh biakan murninya.

Dari hasil penelitian didapat delapan isolat biakan murni yang kemudian diberi kode LT (Limbah Ternak), yaitu LT 1, LT 2, LT 3, LT 4, LT 5, LT 6, LT 7, dan LT 8. Masingmasing isolat kemudian diuji proteolitik pada medium SMA (Skim Milk Agar) pH 8. Isolat yang positif menghasilkan protease ditandai dengan terbentuknya zona jernih di sekeliling koloni. Zona jernih yang terbentuk menunjukkan 
bahwa bakteri menggunakan susu skim yang terdapat pada medium sebagai nutriennya.

Isolat-isolat bakteri yang positif penghasil protease kemudian diuji aktivitasnya dengan metode Kunitz yang dimodifikasi. Isolat bakteri yang mempunyai aktivitas proteolitik tertinggi adalah LT 7 dengan aktivitas sebesar $0,3058 \mathrm{U} / \mathrm{mL}$ yang selanjutnya diidentifikasi. Berdasarkan hasil identifikasi menunjukkan bahwa isolat bakteri LT 7 adalah jenis bakteri yang termasuk ke dalam genus Salmonella sp (data tidak ditampilkan).

\section{Penentuan Waktu Produksi Optimum Enzim Protease dan Kurva Pertumbuhan Isolat Bakteri Salmonella sp.}

Produksi ekstrak kasar enzim protease dilakukan dengan mengekstraksi medium produksi yang telah ditumbuhi isolat bakteri Salmonella sp. pada waktu produksi optimumnya. Pengukuran waktu produksi optimum enzim protease dan fase pertumbuhan isolat bakteri Salmonella sp dilakukan selama 42 jam dan dianalisis setiap 6 jam. Waktu produksi optimum enzim dapat diketahui dengan mengukur aktivitas ekstrak kasar enzim proteasenya. Fase pertumbuhan bakteri ditentukan dengan mengukur kekeruhan medium produksi menggunakan spektrofotometer pada panjang gelombang $600 \mathrm{~nm}$. Kurva hasil pengukuran uji aktivitas relatif enzim protease dan kekeruhan medium produksi terhadap selang waktu dapat dilihat pada Gambar 1.

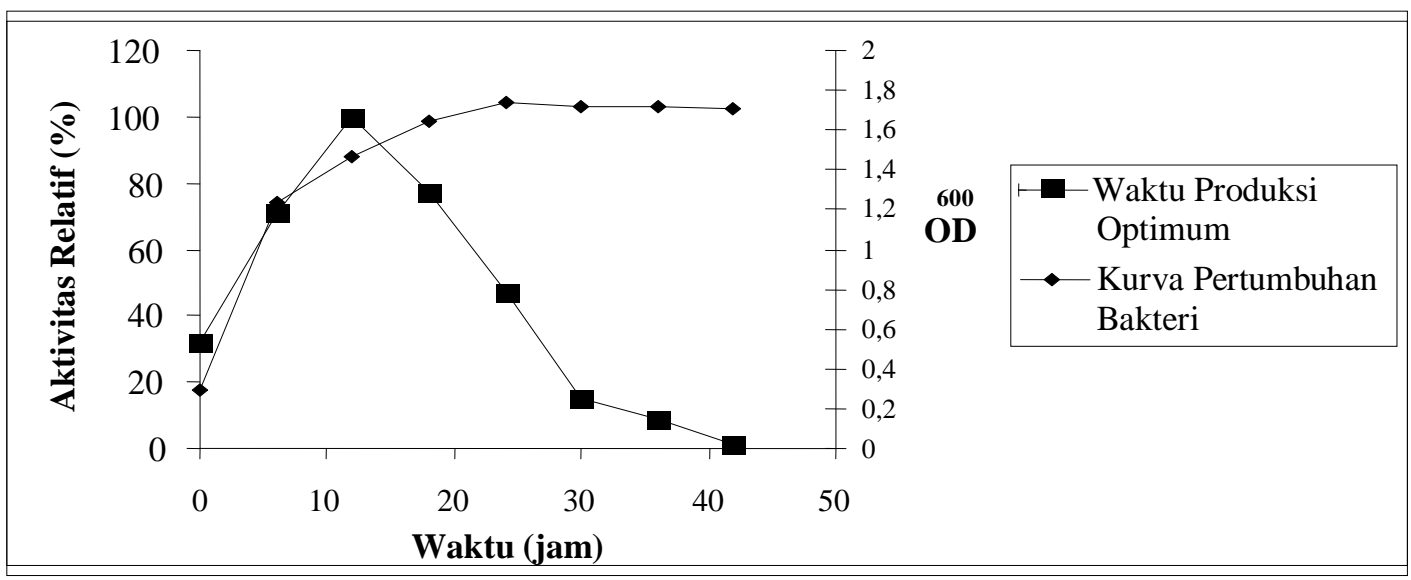

Gambar 1. Waktu produksi optimum protease dan kurva pertumbuhan isolat bakteri Salmonella sp.

Berdasarkan hasil penelitian yang ditunjukkan pada Gambar 1 dapat diketahui bahwa aktivitas relatif protease semakin meningkat dengan bertambahnya waktu dan mencapai optimum pada jam ke-12 dengan aktivitas relatif mencapai $100 \%$. Hal ini menunjukkan bahwa waktu produksi optimum enzim protease dari isolat bakteri Salmonella sp adalah 12 jam. Waktu produksi optimum ini digunakan sebagai waktu produksi enzim protease dari isolat bakteri Salmonella sp. Waktu produksi optimum protease terjadi pada fase eksponensial akhir dari kurva pertumbuhan isolat bakteri Salmonella sp. Menurut Dodia et al. (2006) waktu produksi optimum protease alkalin dari isolat bakteri $\mathrm{S}_{5}$ yang diisolasi dari Coastal Gujarat, India juga terjadi pada akhir fase eksponensial.

\section{Fraksinasi Protease dari Isolat Bakteri Salmonella sp dengan Amonium Sulfat}

Fraksinasi dengan amonium sulfat merupakan salah satu cara pemurnian 
protein melalui proses pengendapan garam. Penambahan garam amonium sulfat akan menurunkan kelarutan protein karena terjadinya kompetisi antara ion garam yang ditambahkan dengan protein yang terlarut sehingga terjadi efek salting out. Fraksinasi amonium sulfat dilakukan dengan konsentrasi 15, 30, 45, dan $60 \%$ jenuh. Hasil pemurnian protease dari isolat bakteri Salmonella sp terlihat dalam Tabel 1.

Tabel 1. Hasil fraksinasi protease dengan amonium sulfat

\begin{tabular}{c|c}
\hline Tahap pemurnian & Unit Aktivitas (U/mL) \\
\hline Ekstrak Kasar & 0,6135 \\
Fraksi $15 \%$ & 0,2521 \\
Fraksi 30\% & 0,8271 \\
Fraksi 45\% & $\mathbf{1 , 4 2 0 8}$ \\
Fraksi 60\% & 0,7813 \\
\hline
\end{tabular}

Dari Tabel 1 dapat dilihat bahwa fraksi $45 \%$ jenuh mempunyai aktivitas protease tertinggi, dengan aktivitas spesifik 1,4208 U/mL, sehingga fraksi 45\% jenuh dikarakterisasi lebih lanjut yang meliputi penentuan suhu optimum, pH optimum, pengaruh logam dan EDTA, pengaruh surfaktan (SDS dan Tween-80), serta kestabilannya terhadap detergen komersial.

\section{Karakterisasi Protease Hasil Fraksinasi Suhu Optimum}

Suhu merupakan salah satu faktor penting yang mempengaruhi aktivitas enzim. Hasil penentuan suhu optimum enzim protease fraksi $45 \%$ dapat dilihat pada Gambar 2.

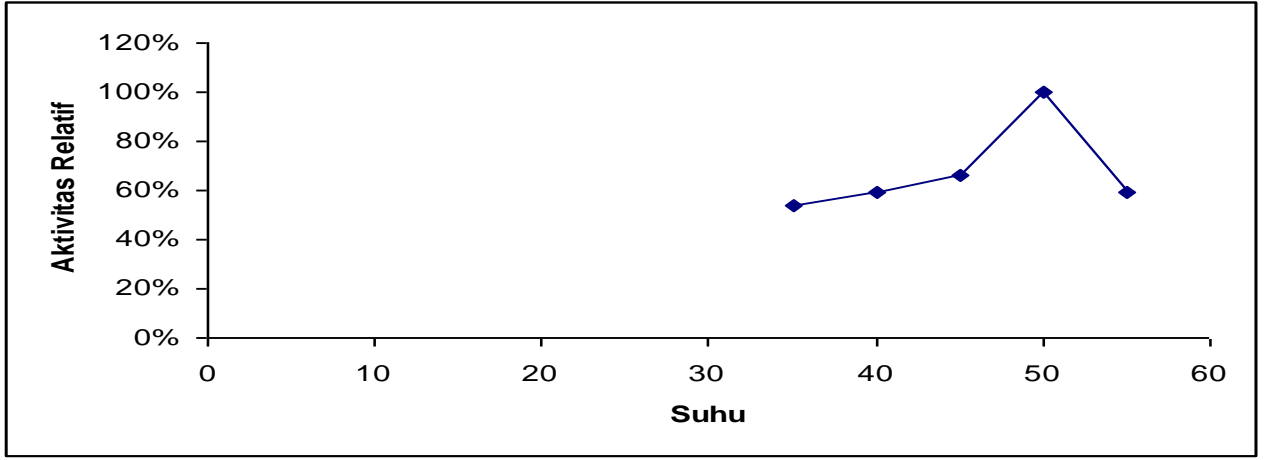

Gambar 2. Pengaruh variasi suhu terhadap aktivitas protease fraksi $45 \%$ dari isolat bakteri Salmonella sp.

Berdasarkan hasil penelitian yang ditunjukkan pada Gambar 2 semakin tinggi suhu maka aktivitas enzim juga akan meningkat sampai terjadi suhu optimum. Aktivitas enzim protease mencapai aktivitas optimum pada suhu $50{ }^{\circ} \mathrm{C}$. Aktivitas protease terus meningkat sampai mencapai suhu optimum disebabkan oleh kenaikan energi kinetik molekul enzim dan juga meningkatnya gerakan molekul-molekul substrat sehingga peluang terjadinya tumbukan antara molekul enzim dan substrat semakin besar. Hal ini mengakibatkan semakin besar pula peluang molekul enzim berikatan dengan substrat sehingga produk yang dihasilkan semakin banyak. Aktivitas enzim juga akan menurun pada suhu di atas suhu optimum. Hal ini disebabkan suhu tinggi akan memecah ikatan-ikatan sekunder seperti ikatan hidrogen yang 
mempertahankan enzim pada struktur alamiahnya, sehingga struktur sekunder, tersier enzim rusak secara partial diikuti dengan menurunnya aktivitas (Roosdiana, dkk., 2002).

\section{pH Optimum}

Salah satu faktor yang mempengaruhi aktivitas protease adalah $\mathrm{pH}$. Hasil penentuan $\mathrm{pH}$ optimum protease fraksi $45 \%$ dari isolat bakteri Salmonella sp. dapat dilihat pada Gambar 3.

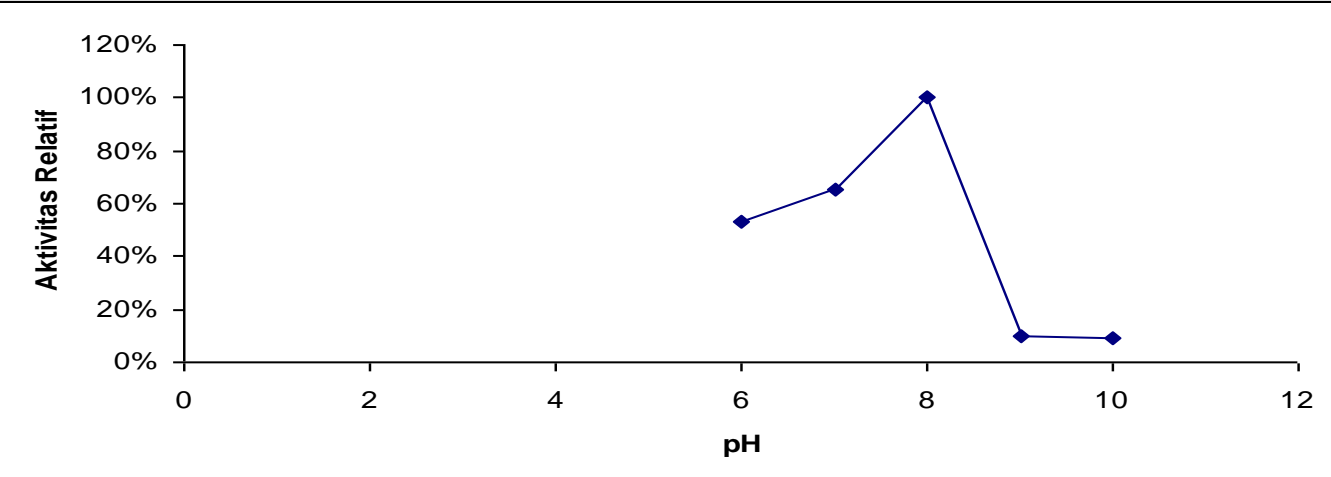

Gambar 3. Pengaruh variasi $\mathrm{pH}$ terhadap aktivitas protease fraksi $45 \%$ dari isolat bakteri Salmonella sp.

Berdasarkan hasil penelitian yang ditunjukkan pada Gambar 3 dapat dilihat bahwa aktivitas optimum protease fraksi $45 \%$ dari isolat bakteri Salmonella sp terjadi pada $\mathrm{pH}$ 8. Protease dari isolat bakteri Salmonella sp. termasuk alkalin protease karena aktif pada $\mathrm{pH}$ alkalin dan dapat diaplikasikan pada industri detergen. $\mathrm{pH}$ optimum yang sama juga dimiliki oleh protease yang diisolasi dari bakteri Bacillus sp. (Naiola dan
Widhyastuti, 2007) dan bakteri termofilik Bacillus sp. (Nascimento and Martins, 2003).

\section{Pengaruh Penambahan Ion Logam dan EDTA}

Pengaruh Penambahan ion logam dan EDTA terhadap aktivitas protease fraksi $45 \%$ dari isolat bakteri Salmonella sp. dapat dilihat pada Gambar 4.

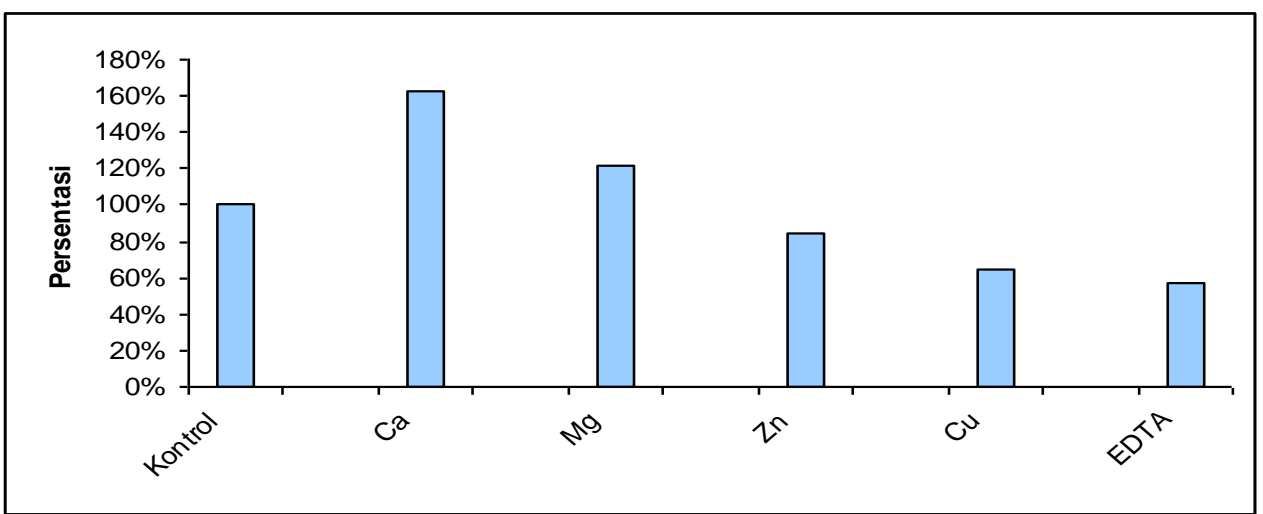

Gambar 4. Pengaruh penambahan ion logam dan EDTA terhadap aktivitas protease fraksi $45 \%$ dari isolat bakteri Salmonella sp.

Berdasarkan hasil penelitian yang ditunjukkan pada Gambar 4 aktivitas relatif protease fraksi $45 \%$ dari isolat bakteri Salmonella sp. turun menjadi 
58\% dengan penambahan EDTA, sehingga protease tersebut termasuk protease logam. Protease logam membutuhkan ion logam untuk aktivitas optimalnya, dan aktivitasnya akan diinhibisi dengan adanya agen pengkelat logam, seperti EDTA (Yang, et al., 2000) Penambahan ion $\mathrm{Ca}^{2+}$ dan $\mathrm{Mg}^{2+}$ pada enzim protease dari isolat bakteri Salmonella sp. dapat meningkatkan aktivitas relatif enzim menjadi $162 \%$ untuk ion $\mathrm{Ca}^{2+}$ dan $122 \%$ untuk ion $\mathrm{Mg}^{2+}$. Data yang dihasilkan tersebut menunjukkan bahwa protease dari isolat Salmonella sp. membutuhkan ion $\mathrm{Ca}^{2+}$ dan $\mathrm{Mg}^{2+}$ untuk meningkatkan aktivitasnya. Menurut Kamelia, dkk. (2005) ion logam $\mathrm{Ca}^{2+}$ dan $\mathrm{Mg}^{2+}$ berperan pada hidrolisis protein yaitu membentuk ikatan kovalen koordinasi dengan residu asam amino dari protease dan bersifat sebagai akseptor elektron (asam Lewis) sehingga mampu berinteraksi dengan basa yaitu gugus $\mathrm{OH}$ dari molekul air.

Ion logam disamping berperan sebagai aktivator dapat juga berperan sebagai inhibitor. Dari hasil penelitian, logam $\mathrm{Cu}^{2+}$ dan $\mathrm{Zn}^{2+}$ berperan sebagai inhibitor enzim protease karena mampu menginhibisi aktivitas protease fraksi $45 \%$ sehingga aktivitas relatif menurun masing-masing menjadi $65 \%$ dan $85 \%$ pada penambahan logam $\mathrm{Cu}^{2+}$ dan $\mathrm{Zn}^{2+}$.

\section{Pengaruh Penambahan Surfaktan (SDS dan Tween-80)}

Surfaktan merupakan zat yang berfungsi untuk menurunkan tegangan permukaan suatu cairan. Surfaktan menurunkan tegangan permukaan air dengan memutuskan ikatan-ikatan hidrogen antar molekul air pada permukaan air. Proses penurunan tegangan permukaan terjadi dengan cara gugus-gugus hidrofilik dari surfaktan mendekati permukaan air dan gugusgugus hidrofobiknya terentang menjauhi permukaan air (Fessenden dan Fessenden, 1982). Surfaktan terbagi menjadi 3 jenis, yaitu surfaktan anionik seperti SDS (Sodium Dodesil Sulfat), surfaktan non ionik seperti Tween-80, dan surfaktan kationik. Pengaruh penambahan surfaktan SDS dan Tween 80 terhadap aktivitas protease fraksi $45 \%$ dari isolat bakteri Salmonella sp. dapat dilihat pada Gambar 5 dan 6.

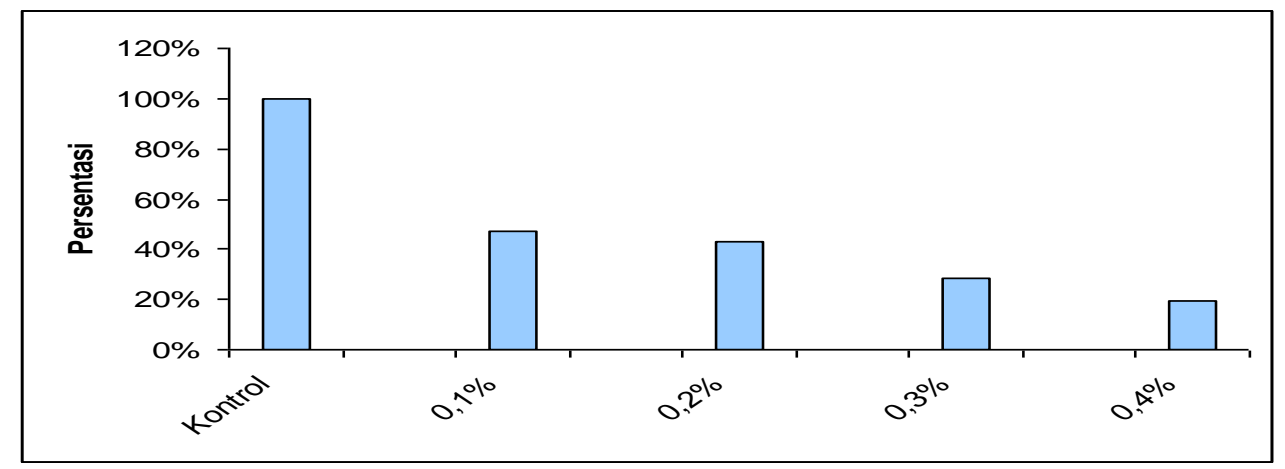

Gambar 5. Pengaruh penambahan SDS terhadap aktivitas protease fraksi $45 \%$ dari isolat bakteri Salmonella sp.

Berdasarkan hasil penelitian yang ditunjukkan pada Gambar 6 aktivitas relatif protease dari isolat bakteri Salmonella sp. tersisa $47 \%$ dengan penambahan $0,1 \%$ SDS. Semakin besar konsentrasi SDS yang ditambahkan maka aktivitas protease semakin hilang. Hal ini menunjukkan bahwa protease dari isolat bakteri Salmonella sp tidak tahan terhadap adanya surfaktan jenis anionik seperti SDS. Aktivitas protease dapat menurun dengan penambahan SDS 
karena kepala hidrofilik SDS yang bersifat anionik dapat mengubah muatan residu asam amino enzim protease dan memutuskan ikatan hidrogen pada protein enzim sehingga konformasi aktif protease berubah. Joo, et al., (2003) melaporkan bahwa dengan penambahan SDS 5\% maka aktivitas protease dari $B$. clausii tersisa $72,6 \%$, sedangkan protease dari P. Aeruginosa PD100 kehilangan aktivitasnya sebesar 50\% (Najafi, et al., 2005).

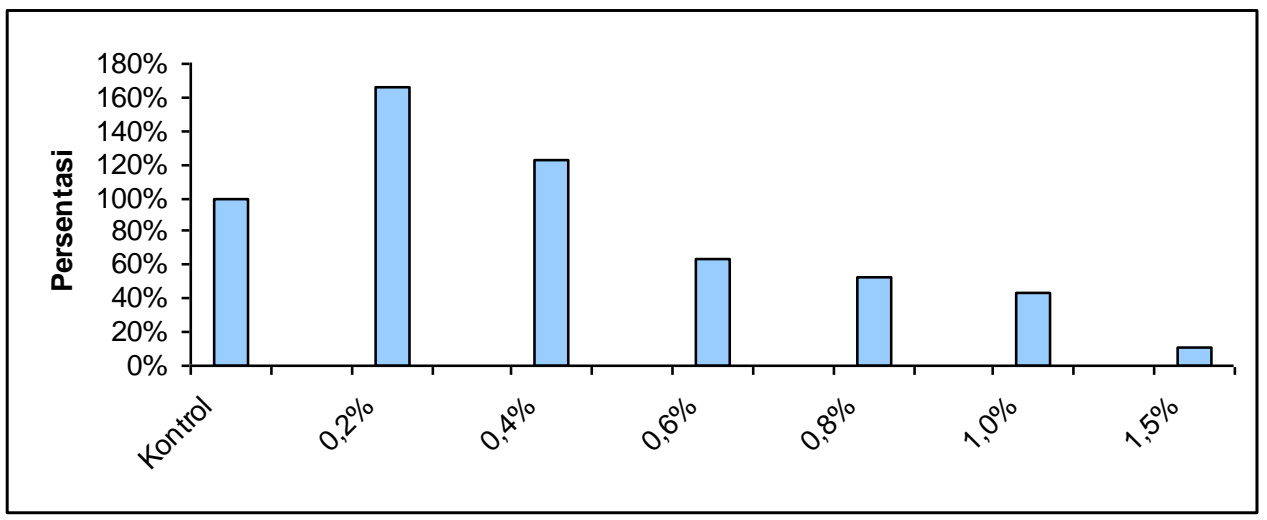

Gambar 6. Pengaruh penambahan Tween-80 terhadap aktivitas protease fraksi $45 \%$ dari isolat bakteri Salmonella $\mathrm{sp}$.

Berdasarkan hasil penelitian yang ditunjukkan pada Gambar 7 aktivitas relatif protease dari isolat bakteri Salmonella sp. meningkat menjadi $165 \%$ dan $123 \%$ dengan penambahan masingmasing $0,2 \%$ dan $0,4 \%$ Tween- 80 . Aktivitas protease kemudian menurun menjadi $64 \%$ dengan penambahan $0,6 \%$ Twen-80. Penambahan Twen-80 dengan konsentrasi yang lebih besar dari $0,6 \%$ membuat aktivitas relatif protease semakin menurun. Hal ini menunjukkan bahwa protease dari isolat bakteri Salmonella sp. relatif lebih tahan terhadap surfaktan jenis non anionik seperti Tween-80 pada konsentrasi sekitar $0,2-0,4 \%$.

\section{Kestabilan Protease dengan Penambahan Detergen Komersial}

Kestabilan protease dari isolat bakteri Salmonella sp dengan penambahan detergen komersial ditentukan dengan melihat besarnya perubahan aktivitas protease setelah diinkubasi pada kondisi optimumnya. Kestabilan protease dari isolat bakteri Salmonella $s p$ dengan penambahan detergen komersial dapat dilihat pada Gambar 7.

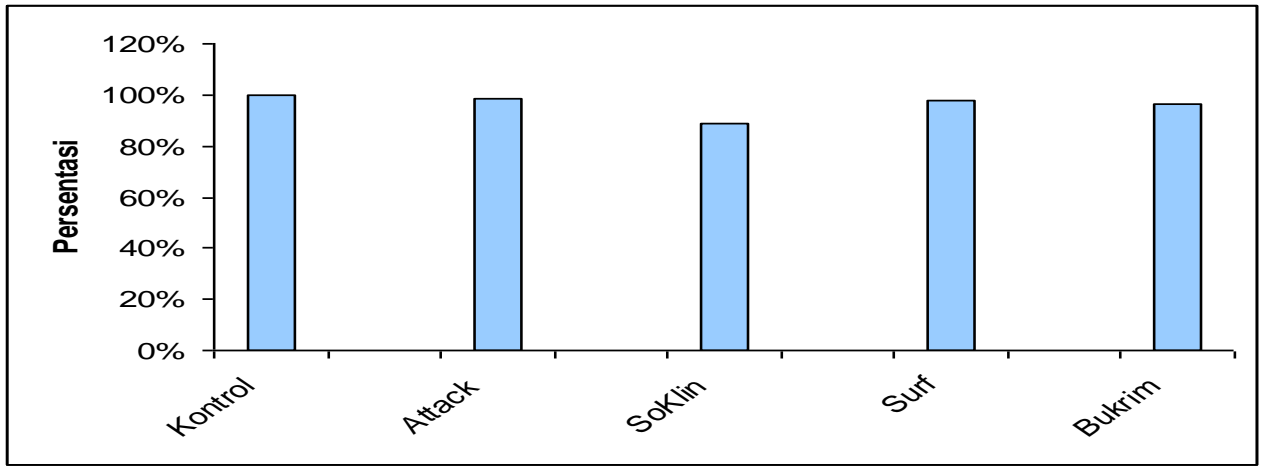

Gambar 7. Kestabilan protease fraksi $45 \%$ dari isolat bakteri Salmonella sp. dengan penambahan detergen komersial 
Protease yang diaplikasikan pada industri detergen harus stabil terhadap keberadaan detergen komersial. Berdasarkan hasil penelitian yang ditunjukkan pada Gambar 7 dapat diketahui bahwa aktivitas protease fraksi 45\% dari isolat bakteri Salmonella sp. dengan penambahan detergen Attack, Soklin, Surf, dan Bukrim masing-masing adalah 98\%, 89\%, $98 \%$ dan $96 \%$. Aktivitas protease fraksi $45 \%$ dari isolat bakteri Salmonella sp. relatif stabil dengan penambahan detergen Attack, Surf, dan Bukrim. Aktivitas protease fraksi $45 \%$ dari isolat bakteri Salmonella sp. relatif menurun dengan penambahan detergen Soklin.

\section{KESIMPULAN}

1. Genus bakteri penghasil protease yang diisolasi dari limbah ternak Exfarm Fakultas Peternakan Universitas Jenderal Soedirman adalah Salmonella sp.

2. Karakteristik protease fraksi $45 \%$ amonium sulfat dari isolat Salmonella sp. memiliki suhu optimum $50{ }^{\circ} \mathrm{C}, \mathrm{pH}$ optimum 8 , diaktivasi oleh ion logam $\mathrm{Ca}^{2+}$ dan $\mathrm{Mg}^{2+}$, serta diinhibisi oleh ion logam $\mathrm{Zn}^{2+}, \mathrm{Cu}^{2+}$, dan EDTA. Penambahan SDS menurunkan aktivitas protease. Penambahan Tween-80 dengan konsentrasi 0,2 dan $0,4 \%$ meningkatkan aktivitas protease, sedangkan penambahan Tween-80 dengan konsentrasi $\geq 0,6 \%$ menurunkan aktivitas protease.

3. Protease dari isolat Salmonella sp. relatif stabil pada penambahan detergen komersial merk Attack, Surf, dan Bukrim.

\section{DAFTAR PUSTAKA}

Adinarayana, K., P. Ellaiah, and D.S. Prasad. 2003. Purification and Partial Characterization of Thermostable Serine Alkaline Protease from a Newly Isolated
Bacillus subtilis PE-11. AAPS PharmSchiTech. 2003;4(4): article 56.

Bollag, D. M., M. D. Rozycki and S. I. Edelstein. 1996. Protein Methods $2^{\text {nd }} E d$. John Willey and Sons. New York.

Dodia, M.S., R.H. Joshi, R.K. Patel, and S.P. $\quad$ Singh. 2006. Characterization and Stability of Extracellular Alkaline Protease from Halophilic and Alkaliphilic Bacteria Isolated from Saline Habitat of Coastal Gujarat, India. Brazilian Journal of Microbiology. 37:276-282.

Fessenden, R.J. dan J.S. Fessenden. 1982. Kimia Organik Jilid 2. Erlangga. Jakarta.

Fuad, A.M., R. Rahmawati, N.R. Mubarik. 2004. Produksi dan Karakterisasi Parsial Protease Alkali Termostabil Bacillus Thermoglucosidasius AF-01. Jurnal Mikrobiologi Indonesia: No 1 ISSN 0853-358X volume 9.

Jaswal, R.K., G.S. Kocher. 2007. Partial Characterization of a Crude Alkaline Protease From Bacillus circulans and Its Detergen Compatibility. Journal of Microbiology. 2007. Volume 4 Number 1.

Joo, H.S., C.G. Kumar, G.-C. Park, S.R. Paik, and C.-S. Chang. 2003. Oxidant and SDS-Stable Alkaline Protease from Bacillus clausii I52: Production and Some Properties. Journal of Applied Mirobiology, 95, 267-272.

Kamelia, R., Sindumarta dan D. Natalia. 2005. Isolasi dan Karakterisasi 
Protease Intraselular Termostabil dari Bakteri Bacillus sterothermophilus RP1. Makalah disampaikan dalam Seminar Nasional FMIPA UI. Depok, 24-26 November 2005.

Najafi, M.F., D. Deobagkar, and D. Deobagkar. 2005. Potential Application of Protease Isolated from Pseudomonas aeruginosa PD100. Electronic Journal of Biotechnology, Vol. 8, No. 2.

Naiola, E dan N. Widhyastuti. 2007. Semi Purifikasi dan Karakterisasi Enzim Protease Bacillus sp. Berk. Penel. Hayati: 13 (51-56).

Nascimento, W.C.A., and M.L.L.Martins. 2003. Production and Properties of An Extracellular Protease from Thermophillic Bacillus sp. Brazillian Journal of Microbiology, 35, 91-96.
Nogueira, E., U. Beshay, and A, Moreira. 2006. Characteristics of Alkaline Protease Enzyme Produce by Teredinobacter turnirae and Its Potential Application as A Detergent Additive. Deutsche Lebensmittel-Rundschau 102, Heft 5, 2006.

Roosdiana, A., H. Kartikaningsih, Suharjono, R. Peranginangin, dan Murdinah. 2002. Isolasi dan Karakterisasi Bacillus sp Penghasil Protease dari Kulit Ikan Kakap Merah (Lutjanus sanguineus). Jurnal Ilmu-Ilmu Hayati (Life Sciences). Vol.14, No.2.

Yang, J.-K., I.-L. Shih, Y.-M. Tzeng, S.L. Wang. 2000. Production and Purification of Protease from Bacillus subtilis That Can Deproteinize Crustacean Wastes. Enzyme and Microbial Technology, 26: 406-413. 